ISSN 0347-8769

Seminar Paper No. 500

\title{
REAL EFFECTS OF THE 1992 FINANCIAL DEREGULATION
}

by

J.-M. Viaene

This paper was presented at the

European Research Workshop in International Trade,

Stockholm, June 14-18, 1991

Seminar Papers are preliminary material circulated to stimulate discussion and critical comment.

September 1991

Institute for International Economic Studies

S-106 91 Stockholm

Sweden 


\title{
Real Effects of the 1992 Financial Deregulation*
}

\author{
J.-M. Viaene \\ Erasmus University \\ Department of Economics \\ P.O. Box 1738, 3000 DR Rotterdam
}

\begin{abstract}
$\underline{\text { Abstract }}$
This paper analyzes the short-run and steady state real effects of financial deregulation in an open economy which trades in commodities and securities. The emphasis is placed on what role these measures play in the physical capital accumulation, portfolio equilibrium, the economy's external indebtedness and in the transition from less than full employment to full employment. On this basis, an assessment is made of the potential effects of the 1992 liberalization of financial services for five European countries and concludes that the strong claims for beneficial effects of financial deregulation are supported by the results.
\end{abstract}

Key Words: asset accumulation, interest rate, physical capital accumulation, portfolio balance.

JEL-Categories: 313, 431. 


\section{INTRODUCTION}

The new freedom on European capital markets came into being after the Council of the European Community adopted, in June 1988, a directive liberalizing the banking sector of the EC countries. The directive involves two sets of liberalizing measures. The first principle, a prerequisite for the implementation of the subsequent one, is the complete liberalization of capital movements. EC member countries had to take measures necessary to comply with this directive no later than July 1, 1990 with longer transition periods for Greece, Ireland, Portugal and Spain. The second principle concerns the liberalization of the financial service industry and consists of three directives: (1) the freedom of establishment, (2) the freedom to sell financial products and services across EC-borders and (3) the harmonization of legal requirements. The aim of these reforms is to reduce the protectionist barriers in the operation of national banking sectors and to improve the role of international markets in the allocative efficiency of the financial system.

The main question of this paper is whether financial deregulation is a chief agent of change. This is an application to Europe of the long debated proposition, summarized in Fry (1988), Dornbusch and Reynoso (1989), that financial repression in LDCs is an impediment to economic development. One of the main attractions the financial deregulation holds for EC policy makers is indeed its potential to stimulate the accumulation of physical capital and thereby push labor employment past its current limits. But while there is some consensus about the capital-augmenting effects of a structural reduction in the cost of capital, in a world of 
free capital movements, the ensuing change in the relative price of domestic assets leads to a portfolio reallocation abroad and at home such that the titles of ownership of the domestic stock of capital might partly fall in foreign hands. This process would increase the economy's net indebtedness with the rest of the world and undermine the prospect of increasing employment.

Although deregulation of the banking sector has been debated for some time, ${ }^{1)}$ a theoretical analysis of the capital-wealth accumulation trade off has yet to appear. This paper develops a simple dynamic model which sheds light on the likely impact of financial deregulation on domestic capital and wealth accumulation of an open economy trading in goods and equities. The basic characteristics of the model are the interaction between the good and asset markets, and the introduction of the physical capital stock in a specialized domestic model. Apart from incorporating the two intervening principles of liberalization the model complies with the double casual evidence that the share of foreign equities in the portfolios of many European institutions is relatively low and that transformations in financial markets occur rapidly whereas capital accumulation develops with delays. The main analytical result supports the financial repression paradigm in that increased bank efficiency is shown to raise the equilibrium stock of physical capital.

Very few empirical results on the liberalization of financial services have appeared so far. $^{2)}$ This study puts forward new evidence on this front by using a simulation technique, initially developed in a different context [Van Dijk and Kloek (1982)]. The technique is applied to five EC countries. 
The simulation experiment falls under the broad category of Monte Carlo experiments: repeated, independent samples are randomly drawn out of a given joint probability distribution defined on the parameter space of the model. Since the model assumes instantaneous clearing on the asset and good markets, it has the simple features of computable general equilibrium models but, at variance with the latter, the technique adopted here allows for thousands of replications of the model. The two principles of financial deregulation can be seen as a reduction in the cost of capital on the one hand and a reduction in the price of financial services on the other hand. The paper contrasts their respective effects and concludes that, in each case, the strong claims for beneficial effects of financial deregulation are supported by the simulation results.

The paper is organized as follows. Section 2 interprets the two principles of financial liberalization in terms of interest rate spreads. The structure of the model and the equilibrium on the commodity and asset markets are described in Section 3. Section 4 deals with the short-run and steady state effects of the liberalization of financial services and of the abolition of capital controls. The dynamic properties of the model are also examined in this section. In Section 5 the model simulations are discussed and the paper ends with concluding remarks.

\section{Economic Significance of the 1992 Financial Deregulation}

The label of capital controls is attached to a very large body of measures. All types of restrictions, though highly diversified, are usually intended 
to achieve a common goal: to constraint the residents' financial decisions to invest abroad. The defense of capital controls is that they are less costly than the movements of exchange rates, interest rates and prices that would ensue without them. The case against capital controls is that they tend to isolate the domestic financial market, and thereby create a wedge between risk-adjusted real terms to investment and saving in different countries [Folkerts-Landau and Mathieson (1989)]. In this sense, the 1992 removal of capital control measures could be expected to have effects through the convergence of real returns to capital among participating countries.

A basic task of the financial institutions is to collect savings by surplus units and transfer them to the deficit units at home or abroad. Existing national financial regulations disrupt this intermediation process by secluding the national market from foreign competition and by imposing rules limiting entry in the industry. Banks are thereby in a position to reap monopoly rents resulting from lower net returns to lenders and higher costs for borrowers. ${ }^{3)}$ In contrast the 1992 shake-up of the regulatory environment is supportive to the intermediation process because the new freedom to supply services across borders no longer allows to ignore differences in the efficiency of banks in different countries. Loans would be supplied by the most efficient financial intermediary who would offer the most attractive terms to borrowers. Similarly, surplus units would search for the most attractive terms to depositors.

To model the above two principles, consider an economy opened to trade in both securities and goods. On the asset market, the economy is assumed to 
be small relative to the rest of the world. Initially, capital controls at home are assumed to be so extensive that the national capital market is completely isolated from foreign competition. Define $i$ as the cost of capital (by arbitrage, the internal rate of return) in absence of intermediation. The intermediacy between firms and households is assumed to be accomplished by a mutual fund. The price of intermediation is the continuous rate $\varepsilon$, which is charged on each unit of money. The mutual fund charges therefore the cost of capital $(i+\varepsilon)$ to firms and gives the return $(\mathrm{i}-\varepsilon$ ) to savers, $2 \varepsilon$ being what is called the spread. Upon the abolition of capital controls and the liberalization in the supply of financial services the world rates $\left(i^{*}+\varepsilon^{*}\right)$ and $\left(i^{*}-\varepsilon^{*}\right)$ will prevail in the domestic economy. For firms it means a change in the cost of capital by $\left[\left(i^{*}-i\right)+\left(\varepsilon^{*}-\varepsilon\right)\right] ;$ for households the change in the return on equities is $\left[\left(i^{*}-i\right)-\left(\varepsilon^{*}-\varepsilon\right)\right]$. Hence, financial deregulation can be represented by two terms, $\mathrm{di}=\mathrm{i}^{*}-\mathrm{i}$ and $\mathrm{d} \varepsilon=\varepsilon^{*}-\varepsilon$, where $\mathrm{d}$ denotes the deviation with respect to the initial equilibrium. Both terms are generally negative: di represents the decrease in the risk premium as a result of the abolition of capital controls and $\mathrm{d} \varepsilon$ is the reduction in the cost of intermediation as home banking is assumed to be less efficient. Hence, the final outcome of the 1992 liberalization differs for savers and borrowers. For firms, it means a clear-cut reduction in the cost of capital; for households, an increase in the returns if the efficiency gain is larger than the loss due to the abolition of capital controls. The next section discusses a real model that is capable of including these differentiated shocks. 


\section{The Model}

On the goods market the domestic economy is assumed to be specialized in the production of a single composite good which is an imperfect substitute for the composite good produced abroad. The domestic and foreign prices are denoted by $\mathrm{p}$ and $\mathrm{p}^{*}$, respectively. The rate of production of the non-monetary sector, $\mathrm{Y}$, is described by the production function

$$
\mathrm{Y}=\mathrm{F}(\mathrm{K}, \mathrm{L})
$$

which is homogenous of degree 1 , where $\mathrm{L}$ denotes labor employment and $\mathrm{K}$ represents the depreciation free domestic stock of capital. The properties of the sectoral production functions are summarized by $\mathrm{F}_{\mathrm{i}}>0$, $\mathrm{F}_{\mathrm{i} \mathrm{i}}<0, \mathrm{~F}_{11} \mathrm{~F}_{22}-\mathrm{F}_{12}=0(\mathrm{i}=1,2)$. As in two-gap models, physical capital requires the imported commodity and the domestic good in the fixed proportions $\delta$ and $(1-\delta)$, with $0<\delta<1$. The nominal price of a unit of installed domestic capital is therefore $(1-\delta) \mathrm{p}+\delta \mathrm{p}^{*}$. Hence, the expression for $\mathrm{p}_{\mathrm{k}}$, the relative supply price of capital in terms of the domestic production, is

$$
\mathrm{p}_{\mathrm{k}}=(1-\delta)+\delta \mathrm{p}^{*} / \mathrm{p}
$$

The choice of the optimal capital stock for the domestic sector satisfies

$$
\mathrm{F}_{1}=(\mathrm{i}+\varepsilon) \mathrm{p}_{\mathrm{k}}-(1-\delta) \dot{\mathrm{p}} / \mathrm{p}-\delta \dot{\mathrm{p}}^{*} / \mathrm{p}
$$

where an overdot denotes a time derivative and $\left[(1-\delta) \dot{\mathrm{p}} / \mathrm{p}+\delta \dot{\mathrm{p}}^{*} / \mathrm{p}\right]$ are the 
capital gains on the existing stock of capital. ${ }^{4)}$ Expression (3) is another way of writing that the real rate of return on equity must equal the marginal physical product of capital divided by the relative price of capital plus the expected percentage rate of change of the price of capital.

From (2) and (3) it is clear that, in the long-run, a drop in the price of the home good leads to an increase in the relative price of domestic capital in excess of the present value of the marginal product $F_{1}$ discounted at $(i+\varepsilon)$, the equality being restored only after a decumulation of the actual capital stock occurs. This adjustment process is given by ${ }^{5}$

$$
\dot{\mathrm{K}}=\lambda\left[\mathrm{F}_{1}-\mathrm{p}_{\mathrm{k}}(\mathrm{i}+\varepsilon)+(1-\delta) \dot{\mathrm{p}} / \mathrm{p}+\delta \dot{\mathrm{p}}^{*} / \mathrm{p}\right] \quad 0<\lambda
$$

where $\lambda$ is the speed of adjustment parameter. The substitution of (2) into (3) gives the long-term marginal condition (with $\dot{\mathrm{p}}=\dot{\mathrm{p}}^{*}=0$ ) for domestic capital in terms of $\mathrm{p}$ and $\mathrm{K}$ whose depiction is given in panel (b) of Figure 1 , the elasticity being $\left.-\left[\left(\mathrm{F}_{11}-\mathrm{F}_{112} \mathrm{~F}_{12}\right) / \mathrm{F}_{2}\right) / \mathrm{i} \delta\right]>0 .^{6)}$

The demand for labor varies to ensure that the nominal wage of labor is equated to the value marginal product of labor

$$
\mathrm{w}=\mathrm{p} \mathrm{F}_{2}(\mathrm{~K}, \mathrm{~L})
$$

Abstracting from anticipated inflation and anticipated changes in productivity, the nominal wage, in turn, adjusts endogenously and the response is approximated by 


$$
\mathrm{w}=\theta\left(\delta \mathrm{p}^{*}+(1-\delta) \mathrm{p}\right) \quad 0<\theta \leq 1
$$

To be parsimonious in the extreme $\delta$ is taken to represent the share of foreign goods in the price index. ${ }^{7}$ ) The positively sloped supply schedule resulting from the present labor market imperfection is obtained by the total differentiation and substitution of $(1),(5)$ and $(6)$ :

$$
\hat{\mathrm{p}}=\left\{\frac{1}{\gamma} \hat{\mathrm{Y}}-\mathrm{k} \hat{\mathrm{K}}\right\} / \theta \delta+\hat{\mathrm{p}}^{*}
$$

where $\gamma=-\mathrm{F}_{2} / \mathrm{F}_{22}>0$ and $\mathrm{k}=\mathrm{F}_{12}+\mathrm{F}_{1} / \gamma>0$ are terms reflecting the production technology and a hat denotes a percentage change. The SS-curve in panel (a) of Figure 1 illustrates equation (7) in the (p, Y) space with elasticity $1 / \gamma \theta \delta>0$. Equation (7) illustrates a neutrality property. As a result of nominal wage indexation and the assumption of imperfect substitutability of commodities, the home terms of trade $\left(\hat{\mathrm{p}}-\hat{\mathrm{p}}^{*}\right)$ are determined by changes in domestic variables only. A once-and-forall increase in the foreign price will not affect any of the steady-state real variables as, by the homogeneity property of demand functions, only relative prices matter. This gives a justification for our single-country approach to liberalization as a multi-country analysis would not lead to different results. Taking $\hat{\mathrm{p}}^{*}=0$ would not matter as well but would make the present analysis simpler and, comparable to the existing literature [Bruce and Purvis (1985), Marston (1985)].

The real value of privately held assets in terms of the production good, A, is defined as 


$$
A=p_{k} K_{d}+M
$$

where $K_{d}$ is the home country's ownership of capital and $M$ is the real value of cash balances. The number of units of capital is identically equal to the number of titles of ownership. If $K_{d}$ exceeds (is less than) $K$, domestic (foreign) households hold foreign (domestic) equities [Frenkel and Rodriguez (1975)]. Initially, $\overline{\mathrm{K}}_{\mathrm{d}}=\overline{\mathrm{K}}$. A first equilibrium relation is portfolio balance, represented by

$$
M=b(i-\varepsilon) p_{k} K_{d} \quad b^{\prime}(i-\varepsilon)<0
$$

that is, the desired ratio of real cash balances to the real value of capital, $b($.$) , is assumed to be a function of the received return on$ equities. Panel (c) of Figure 1 illustrates the solution in $M$ and $K_{d}$ of equations (8) and (9).

Domestic composite consumption of the two goods (in terms of the home good) is based on disposable income $\mathrm{Y}_{\mathrm{d}}$ and a wealth-adjustment process ${ }^{8)}$

$$
C=C\left(Y_{d}, A\right) \quad c_{1}, c_{2}>0
$$

which, together with investment, represent aggregate spending

$$
\mathrm{Y}=\mathrm{C}+\mathrm{p}_{\mathbf{k}} \dot{\mathrm{K}}+\mathrm{B}_{\mathbf{t}}
$$

The two traded commodities being imperfect substitutes, the trade balance is specified in accordance with the elasticity approach 


$$
\mathrm{B}_{\mathrm{t}}=\mathrm{I}^{*}(\mathrm{p})-\mathrm{I}(\mathrm{C}, 1 / \mathrm{p}) / \mathrm{p}-\delta \mathrm{p}_{\mathrm{k}} \dot{\mathrm{K}}
$$

It comprises the foreign demand for domestic goods, I*, and the domestic import demand for foreign goods, I, for the purpose of consumption. The third term in (12), the trade balance in "investment" goods, vanishes in the steady state when stock equilibrium is reached. As expression (10) shows no Laursen-Metzler effect, the elasticity of the aggregate demand function DD in Figure $1 . \mathrm{a}$ is $-1 / \delta \mathrm{Y}\left(\mu^{*}+\mu-1\right)$, where $\left(\mu^{*}+\mu-1\right)$ is the Marshall-Lerner condition.

The services balance, the difference between total output and disposable income, takes the form

$$
B_{s}=p_{k}(i-\varepsilon)\left(K_{d}-K\right)
$$

where $\left(K_{d}-K\right)$ is the foreign ownership. By the balance of payments identity, the current account surplus, $B_{t}+B_{s}$, must be financed by reserve inflows or reductions in net foreign liabilities

$$
\mathrm{B}_{\mathrm{t}}+\mathrm{B}_{\mathrm{s}}=\dot{\mathrm{M}}+\mathrm{p}_{\mathrm{k}}\left(\dot{\mathrm{K}}_{\mathrm{d}}-\dot{\mathrm{K}}\right)
$$

After the differentiation of (8), the use of the identity $\mathrm{Y}_{\mathrm{d}}=\mathrm{Y}+\mathrm{B}_{\mathrm{s}}$ and the substitution of (11) wealth accumulation takes the form

$$
\dot{\mathrm{A}}=\mathrm{Y}_{\mathrm{d}}-\mathrm{C}+\mathrm{K}_{\mathrm{d}} \dot{\mathrm{p}}_{\mathrm{k}}
$$

It is clear from (15) that wealth accumulation is identical to the sum of 
planned saving, $Y_{d}-C$, and unplanned saving, the capital gains $\mathrm{K}_{\mathrm{d}} \dot{\mathrm{p}}_{\mathrm{k}}$.

The model can be summarized so far as consisting of equations (1), (2), (5), (8) to (13) in the 9 endogenous variables $\left\{Y, L, p, p_{k}, C, M, K_{d}, B_{t}\right.$, $\left.\mathrm{B}_{\mathrm{s}}\right\}$ together with the equations (4) and (15) of motion for $\mathrm{K}$ and $\mathrm{A}$ which trace out the sequence of momentary equilibria. The initial equilibrium, is characterized by an average propensity to consume out of disposable income which is unity. With $\mathrm{Y}_{\mathrm{d}}=\mathrm{C}$, the current account is balanced, asset and capital accumulation has ceased, capital gains vanish and the motion of the model comes to rest. With $\mathrm{Y}_{\mathrm{d}}=\mathrm{C}, \delta$ is equal to $\mathrm{I} / \mathrm{Y}$ and parameterizes the openness of the economy. The pre-deregulation equilibrium is characterized by point $O_{1}$ in Figure 1 . In the next section we proceed to disturb the initial equilibrium by reducing the cost of capital by di and by reducing the price of financial services (transaction costs) by $\mathrm{d} \varepsilon .^{9}$

\section{Dynamic Adjustment}

Upon the liberalization of the banking sector and the abolition of capital controls, the world rates, $i^{*}$ and $\varepsilon^{*}$, prevail. With $i^{*}$ lower than $i$ and with $\varepsilon^{*}$ assumed sufficiently lower than $\varepsilon$ such that there is a net gain for savers $(\mathrm{di}-\mathrm{d} \varepsilon>0)^{10)}$, the desired ratio of real balances to equities increases to $b\left(i^{*}-\varepsilon^{*}\right) \vec{p}_{k}$ and instantaneous clearing on the asset market leads to the new portfolio selection $M^{\prime}$ and $K_{d}^{\prime}$. The short-run equilibrium is depicted by point $0_{2}$. In $0_{2}$, domestic investors have exchanged $\left(\bar{M}-M^{\prime}\right)$ of real balances against $\left(\mathrm{K}_{\mathrm{d}}^{\prime}-\overline{\mathrm{K}}_{\mathrm{d}}\right)$ of equities and the domestic ownership of capital has increased. What about the stock of physical capital? With a 
lower cost of capital, the present value of the marginal product $F_{1}$ discounted at $\left(i^{*}+\varepsilon^{*}\right)$ exceeds the relative supply price of capital $\bar{p}_{k}$ and the equality will only be restored if the optimal level of capital stock rises to $\mathrm{K}$ '. Henceforth, the economy starts accumulating and a new demand for investment goods arises. ${ }^{11)}$ In the short-run equilibrium, the stock variables $\mathrm{K}$ and $\mathrm{A}$ are held at their initial steady state values. The capital stock remains thus anchored at $\overline{\mathrm{K}}$. As a result domestic investors own more than the existing capital stock and the home country becomes a net creditor, $\left(K_{d}^{\prime}-\bar{K}\right)$ units of foreign equities being owned by domestic investors. Accordingly, disposable income increases and saving becomes positive. The short-run equilibrium is also characterized by instantaneous clearing on the goods market. On the one hand, the new demand for investment goods causes a rightward shift of the DD-curve. On the other hand, a higher disposable income issued from the new indebtedness of the rest of the world reinforces this movement. Thus, the short-run effects of deregulation produce a clear cut increase in prices and output. With $\overline{\mathrm{K}}$ constant and a higher price in production, the increase in production has been achieved by hiring labor.

The adjustment profile of the open economy in the medium- to long-run is dominated by the profile of real asset and physical capital accumulation. A long-run equilibrium is given by the post-deregulation point $0_{3}$ and is characterized by a lower price for domestic output $\overline{\bar{p}}$ (hence, a higher $\overline{\bar{p}}_{k}$ ) and a real value of wealth, $\overline{\bar{A}}=\overline{\mathrm{M}}+\overline{\overline{\mathrm{p}}}_{\mathrm{k}} \overline{\mathrm{K}}_{\mathrm{d}}$. This point is tentative because forces counteracting each other prevent a sharp outcome in panel (c).

In panel (a) of Figure 1 the capital augmenting effects of deregulation 
Figure 1

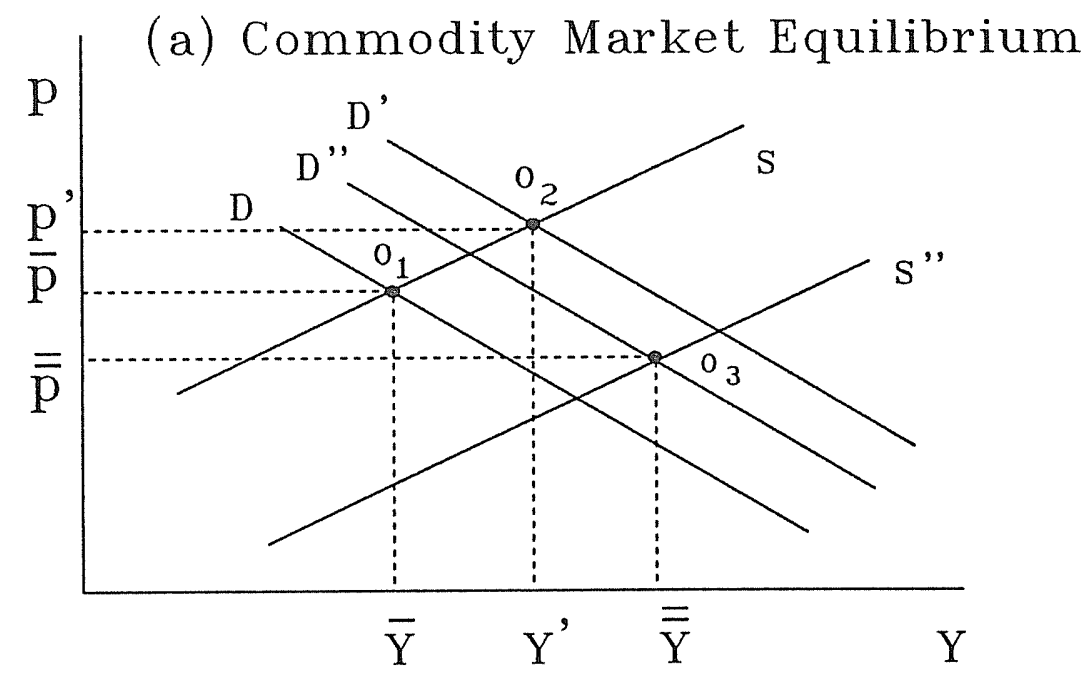

(b) Optimal Capital Stock

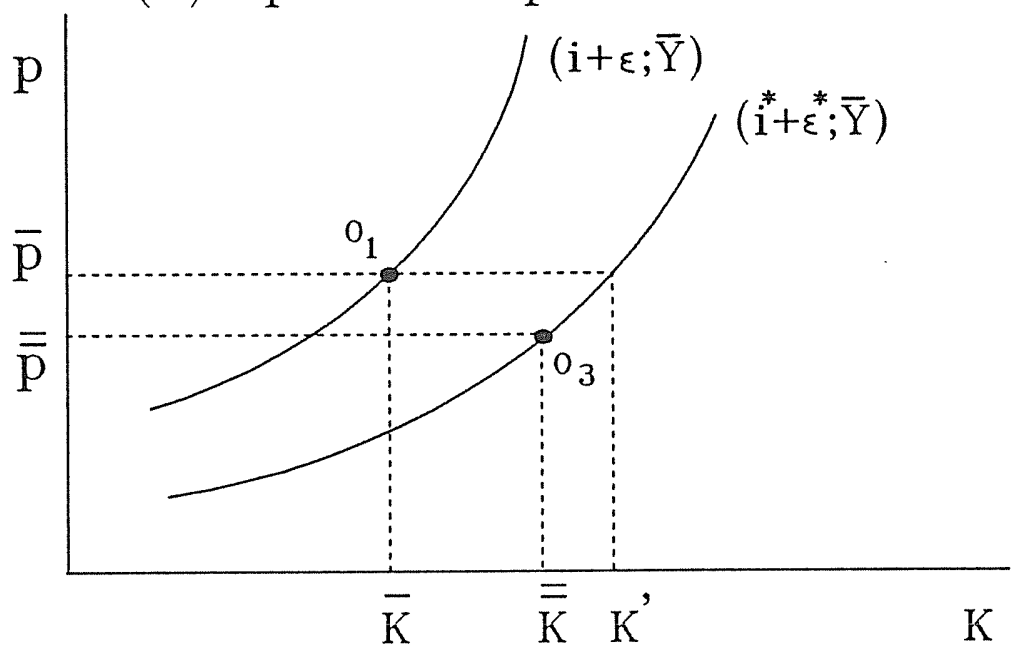

(c) Asset Market Equilibrium

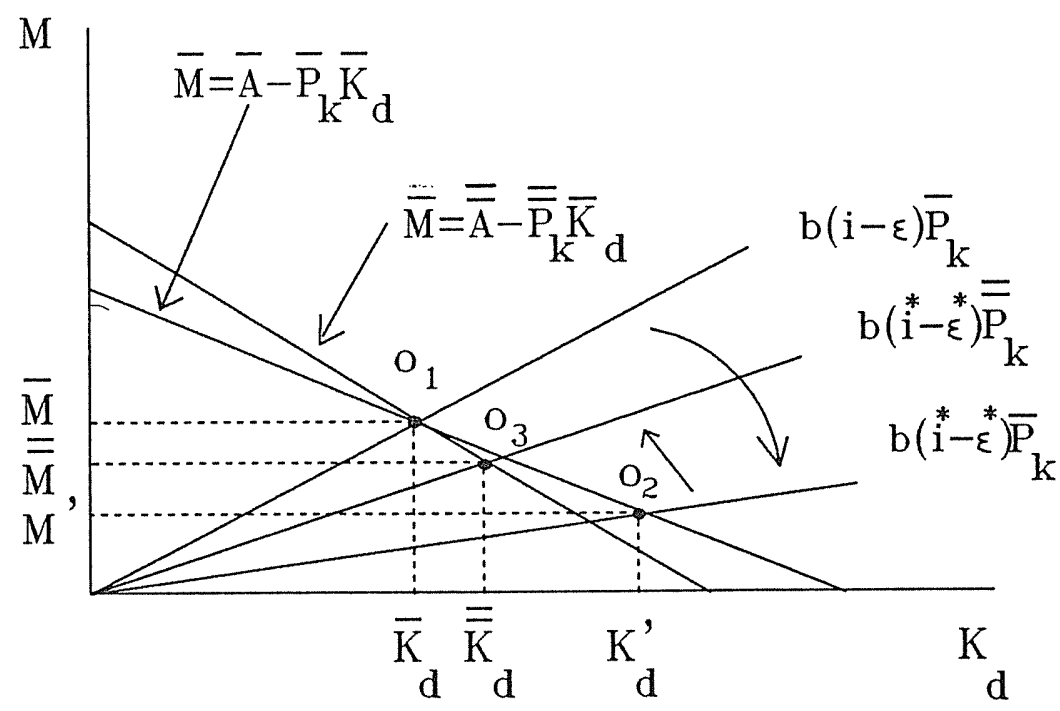


cause a leftward shift of the SS-curve and a drop in the price of home production is needed to clear the market. If the result $\overline{\bar{p}}<\overline{\mathrm{p}}$ is very robust the final outcome for $\mathrm{Y}$ depends on the movement of the DD-curve. For some values of disposable income and wealth, the DD-curve may shift such that $\overline{\mathrm{Y}}<\overline{\mathrm{Y}}, \overline{\overline{\mathrm{p}}}<\overline{\mathrm{p}}$ and for some others the point $0_{3}$ may be located such that $\overline{\mathrm{Y}}>\overline{\mathrm{Y}}$ and $\overline{\overline{\mathrm{p}}}<\overline{\mathrm{p}}$. With a new equilibrium price $\overline{\overline{\mathrm{p}}}$ for the home good, the new relative supply price of capital increases and equals the present value of marginal returns at $\bar{K}$. Thus, overshooting of the long-term optimal stock of physical capital has taken place in the short-run (Note that the long-run marginal condition is drawn with $\mathrm{Y}$ constant). With $\overline{\overline{\mathrm{p}}}_{\mathrm{k}}>\overline{\mathrm{p}}_{\mathrm{k}}$ capital gains on the ownership of domestic capital increase real wealth. In turn, the price rise increases the desired ratio of real balances to equities and the new solution $\left(\overline{\mathrm{M}}, \overline{\mathrm{K}}_{\mathrm{d}}\right)$ is established in accordance with market clearing. This solution with $\overline{\mathrm{K}}_{\mathrm{d}}<\overline{\mathrm{K}}$ is obtained conditional upon wealth taking the real value $\overline{\bar{A}}$. However, the capital price change could be so small (because of a low $\delta$ ) that equilibrium point $0_{3}$ would lie to the south-west of $0_{2}$ in which case, $\overline{\mathrm{K}}<\overline{\mathrm{K}}_{\mathrm{d}}$ would be an equally feasible solution.

Formally, the path the economy follows over time can be more accurately summarized by a two-equation dynamic system in $\mathrm{K}$ and $\mathrm{A}$. Taking first-order Taylor series approximation around the long-run equilibrium values and substituting all relevant equations into (4) and (15) we have

$$
\left[\begin{array}{c}
\dot{K} \\
\dot{A}
\end{array}\right]=\left|1-h_{1} h_{2}\right|^{-1}\left[\begin{array}{ll}
1 & h_{1} \\
h_{2} & 1
\end{array}\right]\left[\begin{array}{ll}
a_{2} / a_{1} & a_{3} / a_{1} \\
b_{2} / b_{1} & b_{3} / b_{1}
\end{array}\right]\left[\begin{array}{l}
d K \\
d A
\end{array}\right]
$$




$$
+\left|1-h_{1} h_{2}\right|^{-1}\left[\begin{array}{ll}
1 & h_{1} \\
h_{2} & 1
\end{array}\right]\left[\begin{array}{ll}
a_{4} / a_{1} & a_{5} / a_{1} \\
b_{4} / b_{1} & b_{5} / b_{1}
\end{array}\right]\left[\begin{array}{l}
d i \\
d \varepsilon
\end{array}\right]
$$

or, in compact matrix form, $\dot{x}=\mathrm{H}_{1} \mathrm{x}^{\prime}+\mathrm{H}_{2} \zeta^{\prime}$. The a's, b's and h's are short-hand notation for expressions which are given in Appendix 2. They have the following sign: $h_{1}>0 ; h_{2}>0 ; a_{1}>0$ under general conditions and is unity in the steady state; $a_{2}<0 ; a_{3}>0 ; a_{4}<0$ under general parameter values; $\mathrm{a}_{5}<0 ; \mathrm{b}_{1}>1 ; \mathrm{b}_{2}<0$ for low values of $\delta ; \mathrm{b}_{3}<0$ for restricted values of $c_{1}$ and $c_{2} ; b_{4}>0 ; b_{5}=-b_{4}<0$.

Dynamic stability requires that

$$
\begin{aligned}
& \operatorname{tr} \mathrm{H}_{1}=\left(\mathrm{a}_{2}+\mathrm{h}_{2} \mathrm{a}_{3}\right) / \mathrm{a}_{1}+\left(\mathrm{b}_{3}+\mathrm{h}_{1} \mathrm{~b}_{2}\right) / \mathrm{b}_{1}<0, \\
& \operatorname{det} \mathrm{H}_{1}=\left(1-\mathrm{h}_{1} \mathrm{~h}_{2}\right)\left(\mathrm{a}_{2} \mathrm{~b}_{3}-\mathrm{a}_{3} \mathrm{~b}_{2}\right) / \mathrm{a}_{1} \mathrm{~b}_{1}>0
\end{aligned}
$$

and is guaranteed if the sufficient conditions, $\left(a_{2}+h_{2} a_{3}\right)<0$ and $b_{3}<0$, are verified. An extreme case is when the production function contains a flat segment and is characterized by a constant marginal product of labor. Then, some parameters take extreme values: $\mathrm{F}_{22}=\mathrm{F}_{12}=0, \gamma=\infty$. It can be shown that the stability conditions simplify substantially and that the characteristic roots become $\lambda_{1}=\lambda \mathrm{F}_{11}<0$, and $\lambda_{2}=\mathrm{b}_{3}$ (which is negative for restricted values of $c_{1}$ and $c_{2}$ ).

Intuitively, the first sufficient condition for stability indicates that the own-effect has to be more negative than the cross-effect and is met 
under general values of the parameters of the model. It stresses the importance of $\lambda$ and $\mathrm{F}_{11}$ whose values are positively correlated with the speed of adjustment of the model towards the new steady state. The second condition for stability, $b_{3}<0$, stresses the role of wealth accumulation in the model (see equation 15)). A rise in real wealth raises disposable income directly by adding the increased yield from additional assets and, consumption expenditure on two accounts, one directly according to the consumption function, one by adding to disposable income. The stability condition assures that the induced planned saving be negative to prevent further accumulation.

The long term response of the endogenous variables across steady states can be obtained by differentiating totally the equations of the model knowing that $\dot{\mathrm{A}}=\dot{\mathrm{K}}=0$ and that $\mathrm{B}_{\mathrm{s}}+\mathrm{B}_{\mathrm{t}}=0$. The expressions for $\mathrm{K}$ and $\mathrm{A}$ are readily obtained from the right hand side of (16):

(19.a) $\left.\hat{\mathrm{K}}=-\frac{\left(\mathrm{a}_{4} \mathrm{~b}_{3}-\mathrm{a}_{3} \mathrm{~b}_{4}\right)}{\left(\mathrm{a}_{2} \mathrm{~b}_{3}-\mathrm{a}_{3} \mathrm{~b}_{2}\right)} \mathrm{di}\right\rangle_{<} 0$

$$
\hat{K}=-\frac{\left(a_{5} b_{3}-a_{3} b_{5}\right)}{\left(a_{2} b_{3}-a_{3} b_{2}\right)} d \varepsilon>0
$$

$$
\hat{A}=-\frac{\left(a_{2} b_{4}-b_{2} a_{4}\right)}{\left(a_{2} b_{3}-a_{3} b_{2}\right) A} d i<0 \quad \text { if } b_{2}<0
$$

$$
\hat{\mathrm{A}}=-\frac{\left(\mathrm{a}_{2} \mathrm{~b}_{5}-\mathrm{a}_{5} \mathrm{~b}_{2}\right)}{\left(\mathrm{a}_{2} \mathrm{~b}_{3}-\mathrm{a}_{3} \mathrm{~b}_{2}\right) \mathrm{A}} \mathrm{d} \varepsilon>0 \quad \text { if } \mathrm{b}_{2}>0
$$

Expressions (19) and (20) are quasi-elasticities and express the percentage response of $\mathrm{K}$ and $\mathrm{A}$ to di and $\mathrm{d} \varepsilon$, a decrease in the cost of capital and in 
the transaction costs respectively. It is clear from (19.b) and (20.b) that we can reach the following conclusion.

Proposition. Consider the 1992 financial deregulation in the long-run. A reduction in the price of financial services results in: (a) an increase in the steady state stock of physical capital; and (b) an increase in the steady state real value of wealth if the sufficient condition $b_{2}>0$ is satisfied.

An equally strong conclusion cannot be reached analytically when discussing the decline in i. The latter effect decreases the new steady state value of assets if $b_{2}<0$ and the effect on the stock of physical capital cannot be signed a priori. Referring to Figure 1.b, this would be the case if the $\left(i^{*}+\varepsilon^{*} ; \bar{Y}\right)$ schedule were allowed to shift in accordance with the movements of $Y$.

The portfolio selection is obtained from the total differentiation of $\mathrm{p}_{\mathbf{k}} \mathrm{K}_{\mathbf{d}}=(1+\mathrm{b}(\mathrm{i}-\varepsilon))^{-1} \mathrm{~A}$, which after making use of $(2)$ is

$$
\hat{\mathrm{K}}_{\mathrm{d}}=\hat{\mathrm{A}}+\delta \hat{\mathrm{p}}-(\mathrm{di}-\mathrm{d} \varepsilon) \mathrm{b}^{\prime} /(1+\mathrm{b}(\mathrm{i}-\varepsilon))
$$

which can take a different sign or a different magnitude according to the shock one considers. The long term response of the other variables of the model can be obtained in a similar way, by differentiating totally the relevant equations:

$$
\hat{\mathrm{Y}}=\mathrm{A} \pi_{1} \hat{\mathrm{A}}+\pi_{2} \hat{\mathrm{K}}+\pi_{3}(\mathrm{di}-\mathrm{d} \varepsilon) ; \quad \pi_{1}>0, \pi_{2}>_{<} 0, \pi_{3}>0,
$$




$$
\hat{\mathrm{p}}=\left(\gamma^{-1} \hat{\mathrm{Y}}-\mathrm{kK}\right) / \theta \delta
$$

$$
\hat{\mathrm{p}}_{\mathrm{k}}=-\hat{\delta \mathrm{p}}
$$

$$
\hat{\mathrm{L}}=\left(\hat{\mathrm{Y}}-\mathrm{F}_{1} \hat{\mathrm{K}}\right) / \mathrm{F}_{2} \mathrm{~L}
$$

$$
\mathrm{dB}_{\mathrm{s}}=(\mathrm{i}-\varepsilon)\left(\hat{\mathrm{K}}_{\mathrm{d}}-\hat{\mathrm{K}}\right)
$$

$$
\mathrm{dB}_{\mathrm{t}}=-\delta \mathrm{Y}\left(\mu^{*}+\mu-1\right) \hat{\mathrm{p}}-\mathrm{mY}
$$

with $\mathrm{dB}_{\mathrm{s}}=-\mathrm{dB}_{\mathrm{t}}$. Expressions (22) to (27), though simple, cannot be signed a priori because of the ambiguity of the sign of $\hat{A}$ and $\hat{K}$. Take the simplest case of the reduction in transaction $\cos t s(\mathrm{~d} \varepsilon<0)$. Without further hypothesizing about parameter values, not much more can be said then: $\hat{K}>$ $0, \hat{\mathrm{A}}>0$ if $\mathrm{b}_{2}>0, \hat{\mathrm{Y}}>0$ if $\pi_{2}>0, \hat{\mathrm{p}}<0$ and $\hat{\mathrm{L}}<0$ if the effect of $\hat{\mathrm{K}}$ is greater than that of $\hat{\mathrm{Y}}, \hat{\mathrm{K}}_{\mathrm{d}}<0$ if the price effect dominates, $\mathrm{dB}_{\mathrm{s}}=-\mathrm{dB}_{\mathrm{t}}<$ 0. Hence, thorough analysis of the deregulation scenarios can only be dealt with if a taxonomical analysis of the parameters of the model is undertaken. Numerical solutions of the model may prove, instead, to be more tractable since most parameters of the model are identifiable in the empirical literature.

\section{The Simulation Experiment}

The simulation exercise we consider falls under the broad category of Monte 
Carlo experiments and offers approximate solutions by means of simulation using random numbers taking into account the known range of the parameters of the model. For reasons of data availability and of compliance to the model's assumption, the following 5 EC countries were selected: Belgium including Luxembourg (BL), France (FR), Italy (IT), Netherlands (NL) and the United Kingdom (UK). These countries are similar in that they all face unemployment, trade in final and intermediate goods, but differ in the asset preferences, the trade openness and in the Marshall-Lerner condition. For each country a sample consists of independently drawn values for the following 6 parameters of the model: $\mu, \mu^{*}, \mathrm{c}_{1}, \mathrm{c}_{2}, \mathrm{~b}^{\prime}$ and $\sigma$. The parameter $\sigma$ is the elasticity of substitution between labor and capital in the domestic sector which, when combined with $\mathrm{F}_{2}=1$ and $\mathrm{F}_{1}=0.1$, produces values for $\mathrm{F}_{11}, \mathrm{~F}_{22}$ and $\mathrm{F}_{12}$.

The long-run parameter estimates for $\mathrm{c}_{1}, \mathrm{~b}^{\prime}, \mu$ and $\sigma$ and their standard deviation are taken from the European Commission's QUEST models [Brandsma et al. (1991)]. QUEST does not, however, provide estimates for $c_{2}$ and $\mu^{*}$. The empirical literature on these two parameters is contrasting. On the one hand, the information on $c_{2}$ is known only for IT [Modigliani and Tarantelli (1975)] and is therefore assumed common to all countries. On the other hand a long but diverging list of estimates exists for $\mu^{*}$ [Goldstein and Khan (1985)]. As a result, the prior information on the parameter space of the model is taken to be a univariate normal distribution for all parameters except for $\mu^{*}$. The drawings are done within one standard deviation of the known estimates. The distribution of $\mu^{*}$ is assumed uniform and the drawings are within the interval of known values. Table 1 outlines, for each parameter, its bounded region by indicating its mean, the upper and lower 
Table 1

Mean, Lower and Upper Bounds of Parameter Drawings

$\begin{array}{lllll}\text { BL } & \text { FR } & \text { IT } & \text { NL } & \text { UK }\end{array}$

$\begin{array}{lllllll} & & & & & & \\ \mathrm{c}_{1}{ }^{\mathrm{a})} & & & & & & \\ & & & & & & \\ & \text { mean } & .791 & .864 & .874 & .896 & .856 \\ & \text { lower } & .483 & .686 & .707 & .707 & .638 \\ & \text { upper } & .990 & .990 & .990 & .989 & .989\end{array}$

\begin{tabular}{|c|c|c|c|c|}
\hline mean & .501 & .484 & .504 & .416 \\
\hline lowe & .450 & .345 & .450 & .185 \\
\hline upper & .550 & .685 & .550 & .752 \\
\hline
\end{tabular}

$\begin{array}{rrrrrrr}\mu^{\text {a) }} & & & & & & \\ & \text { mean } & 2.665 & 2.282 & .463 & 1.561 & .657 \\ & \text { lower } & 1.551 & 1.185 & .304 & 1.129 & .288 \\ & \text { upper } & 4.235 & 4.011 & .667 & 2.138 & 1.168 \\ \mu^{* \mathrm{~b})} & & & & & & \\ & & & & & & \\ & \text { mean } & 1.209 & 1.316 & 1.887 & 1.643 & .934 \\ & \text { lower } & .840 & .340 & .253 & .592 & .322 \\ & \text { upper } & 1.570 & 2.269 & 3.286 & 2.719 & 1.469\end{array}$

\begin{tabular}{|c|c|c|c|c|}
\hline$\delta^{\text {c) }}$ & .650 & .213 & .181 & .504 \\
\hline$b(i-\varepsilon)^{d)}$ & .105 & .199 & .164 & .196 \\
\hline
\end{tabular}

\section{Common To All Countries}

\begin{tabular}{|c|c|c|c|}
\hline e) & & & \\
\hline mean & .092 & mean & -.171 \\
\hline lower & .071 & lower & -.219 \\
\hline upper & .113 & upper & -.124 \\
\hline
\end{tabular}

Sources: (a) Brandsma et al. (1991); (b) Goldstein and Khan (1985), (c) Eurostat (1990); (d) OECD (1989), Bank of England (1989) for UK;

(e) Modigliani and Tarantelli (1975). 
model the country values for $\mathrm{b}$ and $\delta$ characterize the initial equilibrium. $^{13)}$

For each individual country we performed 1,000 replications $^{14}$ ), each time plugging the parameter values in the steady state response of the 9 endogenous variables of the model, equations (19) to (27). Table 2 gives the response of the variables to $\mathrm{di}$ and $\mathrm{d} \varepsilon$ by noting (i) the mean values which have been obtained, (ii) the standard deviation (in parentheses) and (iii) the probability that it takes a negative value ${ }^{15}$ ). Besides the known variables like $\hat{K}, \hat{A}, \hat{p}_{\mathbf{k}}, \hat{Y}, \hat{L}$, we also report results for $\left(\hat{K}_{d}-\hat{K}\right)$, the net credit position of the country with respect to the rest of the world (if premultiplied by $(\mathrm{i}-\varepsilon)$, the services balance $\left.\mathrm{dB}_{\mathrm{s}}=-\mathrm{dB}_{\mathrm{t}}\right)$. Results for these variables express quasi-elasticities, the percentage response to di and $\mathrm{d} \varepsilon$, the latter expressed in percentage points. The speed at which the economy is moving towards equilibrium is given by the mean eigen values $\left(\lambda_{1}, \lambda_{2}\right)$, the smaller one in absolute value dominating the adjustment process.

Three remarks will ease the interpretation of the simulation results of Table 2. First, for each variable, the figures for di and $d \varepsilon$ are expressed in similar units and thereby lend themselves for summation, as an approximation for the global effects of the 1992 financial deregulation. Second, a prerequisite to the last one, the quantitative results presented in Table 2 have a general value. The model having been linearized, the results are not conditional upon the chosen magnitude of the decrease in $i$ and $\varepsilon$ : a reduction by 0.02 instead of 0.01 would double the results without affecting any of the probabilities. It needs no explanation that an 
Table 2

Simulation Results for Five EC Countries:

Abolition of Capital Controls ( $\mathrm{di}<0$ ) and

Reduction in Transaction Costs $(\mathrm{d} \varepsilon<0)$

$\begin{array}{lllll}\text { BL } & \text { FR } & \text { IT } & \text { NL } & \text { UK }\end{array}$

\begin{tabular}{|c|c|c|c|c|c|}
\hline$\hat{\mathrm{K}}$ di & $6.04(.05)$ & $3.88(.08)$ & $2.05(.08)$ & $3.56(.03)$ & $1.16(.03)$ \\
\hline $\operatorname{Pr}(<0)$ & .0 & .0 & .04 & .0 & .03 \\
\hline $\mathrm{d} \varepsilon$ & $4.25(.07)$ & $2.65(.12)$ & $1.48(.11)$ & $1.15(.02)$ & $.63(.04)$ \\
\hline $\operatorname{Pr}(<0)$ & .0 & .0 & .0 & .0 & .0 \\
\hline$\hat{A}$ di & $8.44(.30)$ & $5.02(.24)$ & $2.13(.19)$ & $1.59(.06)$ & $-.44(.09)$ \\
\hline $\operatorname{Pr}(<0)$ & .0 & .001 & .31 & .01 & .74 \\
\hline $\mathrm{d} \varepsilon$ & $6.16(.44)$ & $3.60(.34)$ & $1.86(.30)$ & $.55(.04)$ & $.28(.15)$ \\
\hline $\operatorname{Pr}(<0)$ & .0 & .0 & .22 & .004 & .58 \\
\hline$\hat{\mathrm{Y}} \mathrm{di}$ & $3.11(.05)$ & $2.95(.08)$ & $1.21(.07)$ & $1.68(.02)$ & $-.14(.03)$ \\
\hline $\operatorname{Pr}(<0)$ & .0 & .0 & .28 & .0 & .61 \\
\hline $\mathrm{d} \varepsilon$ & $2.23(.06)$ & $2.07(.11)$ & $1.01(.11)$ & $.56(.02)$ & $.10(.04)$ \\
\hline $\operatorname{Pr}(<0)$ & .0 & .0 & .20 & .0 & .47 \\
\hline$\hat{\mathrm{p}}_{k} \mathrm{di}$ & $.65(.00)$ & $.21(.00)$ & $.19(.00)$ & $.50(.00)$ & $.28(.00)$ \\
\hline $\operatorname{Pr}(<0)$ & .0 & .0 & & .0 & .0 \\
\hline $\mathrm{d} \varepsilon$ & $.45(.00)$ & $.13(.00)$ & $.11(.00)$ & $.16(.00)$ & $.12(.00)$ \\
\hline $\operatorname{Pr}(<0)$ & .0 & .0 & .0 & .0 & .0 \\
\hline$\left(\hat{\mathbb{K}}_{d}-\hat{\mathbf{K}}\right) \mathrm{di}$ & i $1.58(.26)$ & $.75(.16)$ & $-.28(.11)$ & $-2.65(.05)$ & $-2.06(.06)$ \\
\hline $\operatorname{Pr}(<0)$ & .60 & .66 & & .94 & .97 \\
\hline $\mathrm{d} \varepsilon$ & $1.57(.37)$ & $.92(.23)$ & $.38(.19)$ & $-.71(.03)$ & $-.40(.11)$ \\
\hline $\operatorname{Pr}(<0)$ & .56 & .60 & .75 & .92 & .93 \\
\hline$\hat{L} \quad$ di & $2.79(.05)$ & $2.85(.08)$ & $1.12(.07)$ & $1.47(.02)$ & $-.28(.03)$ \\
\hline $\operatorname{Pr}(<0)$ & .0 & .001 & .30 & .006 & .70 \\
\hline $\mathrm{d} \varepsilon$ & $2.00(.07)$ & $2.00(.12)$ & $.95(.11)$ & $.49(.02)$ & $.04(.04)$ \\
\hline $\operatorname{Pr}(<0)$ & .0 & .0 & .22 & .002 & .57 \\
\hline$\lambda_{1}$ & -.036 & -.036 & -.039 & -.067 & -.046 \\
\hline$\lambda_{2}$ & -.082 & -.154 & -.215 & -.132 & -.183 \\
\hline
\end{tabular}

Note. For each variable and for $\mathrm{di}$ and $\mathrm{d} \varepsilon$ are reproduced: the mean simulation value, the standard deviation (in parentheses) and the probability of a negative response (under mean value). 
increase instead of a reduction would produce the opposite effects, the probabilities being then the complementary. Third, how can we justify the magnitude of the impulses? On transaction costs, Price Waterhouse (1988) gives country estimates of the potential percentage price falls of banking services and reduction of the stock exchange transactions resulting from the freeing of the 1992 financial services. Weighing these two estimates by their respective shares in the financing of non-financial corporations [OECD (1989)] gives the country values for $\mathrm{d} \varepsilon$ : -0.0069 (BL), -0.0063 (FR), -0.0060 (IT), -0.0032 (NL) and -0.0042 (UK). On di, the evidence is less clear. A recent analysis [Cho et al. (1986)] concludes that the European capital markets are not yet integrated in the sense that there exists a better international portfolio selection that would yield a lower mean return but with much reduced risk. As no estimate of the reduction in mean return is given and since there is considerable movement of capital already we picked a $10 \%$ reduction which amounts to $\mathrm{di}=-0.01$ across the board. In light of the second remark above, any other change in di is readily computed.

First consider the liberalization of capital movements $(\mathrm{di}<0)$. The attraction that the latter holds for EC policymakers is confirmed by the results of Table 2. The build-up of the stock of physical capital $(\hat{\mathrm{K}})$ is expected to increase with almost certainty in all countries. As predicted by the graphical analysis a decline in the price of home goods (a rise in $\mathbf{p}_{\mathbf{k}}$ ) ensues subsequently with probability 1 . In turn, with $\delta<1$, nominal wages do not decrease to the full extent of prices and, the real wage rate tends to increase above the marginal product of labor. The difference is instantaneously resorbed, in first instance, by the increased capital stock 
and, in second instance, by the variable level of employment. Except for UK, the abolition of capital controls increases the steady state level of employment $(\hat{\mathrm{L}})^{16)}$. A similar pattern of response is obtained for $\hat{\mathrm{Y}}$.

The increase in the relative supply price of capital together with a lower return lead to a higher desired ratio of real balances to equities and, with constant real wealth, to a lower portfolio holding of equities. However, because of capital gains on the initial holding of equities and of induced savings, real wealth $(\hat{A})$ increases on average, except for UK. For countries (IT, NL, UK) where the holding of equities increases on average less than the capital stock, part of the domestic capital stock turns in foreign hands $\left(\hat{K}_{d}-\hat{K}<0\right)$. The interest-account of the balance of payments becomes negative, the trade balance positive. For BL and FR in contrast the opposite occurs.

Turn now to the liberalization of financial services $(\mathrm{d} \varepsilon<0)$. The interpretation of the results differs from the one associated with di only in that, while a lower return on capital previously led to a higher desired ratio of real balances to equities, lower transaction costs lead instead to a lower desired level of that ratio and, hence, to a higher holding of equities. This is shown in Table 2 by relatively greater values for $\left(\hat{K}_{d}-\right.$ $\hat{\mathrm{K}})$. For the rest, the results do not differ much in terms of sign and probabilities.

Finally, the country comparison stresses the results' sensitivity to parameters characterizing trade and consumption expenditure. Look at the di shock which is common to all countries. It is clear by (15) that 
economies with a relatively low propensity to spend (BL, FR, UK) are supposed to accumulate more wealth. Import/export price elasticities, however, matter as well. A first observation from Table 2 is that economies with larger import/export price elasticities (BL, FR, NL) gain more than others in terms of e.g. $\hat{Y}$. This is so because the trade balance and aggregate demand effects of a given price decrease turn out larger for these countries. The degree of openness plays an important role as well, for several conflicting reasons. A high $\delta$ implies a higher increase in the relative price of capital and hence, a less strong accumulation of physical capital and a lower holding of equities $(b($.$) being predetermined after the$ shock).

\section{Concluding Remarks}

The main objective of this paper was to construct an analytical framework capable of analyzing the upcoming 1992 financial deregulation. In particular, the focus was placed on whether the latter is a chief agent of change. We have claimed, for reasons of diverging incidence on the economy, that the planned deregulation can be split into two principles: the liberalization of capital movements, on the one hand, and the liberalization of financial services on the other hand. For each principle a similar trade off between wealth and capital stock accumulation exists in that, in a world of free capital movements, firms' investment plans and wealth owners' portfolio allocation may not operate in conjunction and may be affected in such a way that ownership of part of the domestic capital stock might fall in foreign hands. 
The extent to which this might happen is given analytically and measured through model simulations. Because capital controls and inefficient banking services are characterizing, totally or in part, the EC countries we distinguished between the real effects engineered by the two principles in order to have the net contribution of each. The evidence on the beneficial long term effects is rather strong and supportive of the idea that most participating EC countries are now in a position to reap large gains from the financial deregulation.

\section{Footnotes}

*Many helpful comments on an earlier draft were received from $\mathrm{P}$. Broer, H. Dellas, D. Fausten, D.W. Jansen, C. van Marrewijk, P. Reding, and audiences at the 1990 Lisbon meeting of the European Economic Association and the 1991 European Research Workshop in International Trade at the Institute for International Economic Studies, Stockholm. I am also grateful to A. Brandsma of the Commission of the EC for providing the parameter estimates of the QUEST model. Thanks are also due to A. van Haasteren, M. Herreman, P. Stork and A. de Vaal for their able and diligent research assistance at various stages of this research.

1. A considerable amount of attention has been directed towards the evaluation of possible consequences of 1992 on the future of the banking industry. See e.g. Neven (1989), Steinherr and Gilibert (1989), Giovannini and Mayer (1991). 
2. A rather elaborate study is Price Waterhouse (1988) which provides a first attempt at quantifying the static welfare gains for consumers of the 1992 financial deregulation.

3. The spread between the deposit rate and the lending rate provides first evidence on the allocative inefficiency of a financial system. For the purpose of illustration, recall the interest rate spreads reported in the widely quoted Cecchini report on the cost of "non-Europe": Luxemburg $\simeq 2 \%$, Belgium-Netherlands $\simeq 3 \%$, Italy $\simeq 4 \%$, France-Germany $\simeq$ $5 \%$, UK $\simeq 7.5 \%$. Other elements like price instability [Capoglu (1990] and banking risks [Melitz and Bordes (1991)] can, however, partly explain the country differences.

4. Capital gains on the existing capital stock do not affect the long term value of the variables, but do affect the stability conditions of the model in a minor way. For a particular set of parameter values, the characteristic roots of the model are -0.053 and -0.125 without capital gains, and -0.055 and -0.105 with capital gains.

5. To arrive at equation (4) consider the steady state marginal condition of domestic capital $\overline{\mathrm{F}}_{1}=\mathrm{p}_{\mathbf{k}}(\mathrm{i}+\varepsilon)-(1-\delta) \dot{\mathrm{p}} / \mathrm{p}-\delta \dot{\mathrm{p}}^{*} / \mathrm{p}$. This is equivalent to $\mathrm{F}_{1}-\overline{\mathrm{F}}_{1}=\mathrm{F}_{1}-\mathrm{p}_{\mathrm{k}}(\mathrm{i}+\varepsilon)+(1-\delta) \dot{\mathrm{p}} / \mathrm{p}+\delta \dot{\mathrm{p}}^{*} / \mathrm{p}$. We also know that $\mathrm{F}_{1} \simeq \overline{\mathrm{F}}_{1}+\overline{\mathrm{F}}_{11}(\mathrm{~K}-\overline{\mathrm{K}})$ and, by substitution, that $(\mathrm{K}-\overline{\mathrm{K}}) \simeq\left[\mathrm{F}_{1}-\right.$ $\left.\mathrm{p}_{\mathrm{k}}(\mathrm{i}+\varepsilon)+(1-\delta) \dot{\mathrm{p}} / \mathrm{p}+\delta \dot{\mathrm{p}}^{*} / \mathrm{p}\right] / \overline{\mathrm{F}}_{11}$. The adjustment of the capital stock is $\dot{\mathrm{K}}=\lambda^{\prime}(\overline{\mathrm{K}}-\mathrm{K})$ and, after subsitution of the previous expression, it can be rewritten as $\dot{\mathrm{K}}=\lambda\left[\mathrm{F}_{1}-\mathrm{p}_{\mathbf{k}}(\mathrm{i}+\varepsilon)+(1-\delta) \dot{\mathrm{p}} / \mathrm{p}+\delta \dot{\mathrm{p}}^{*} / \mathrm{p}\right]$ with $\lambda=-\lambda^{\prime} / \overline{\mathrm{F}}_{11}$. 
6. Without loss of generality, we define the units of measurement so that $\overline{\mathrm{K}}=\overline{\mathrm{Y}}=1$. In addition the initial equilibrium is characterized by $\overline{\mathrm{p}}^{*}=\overline{\mathrm{p}}$ $=1$.

7. A wide array of alternatives linking the labor market and the terms of trade can be taken up. The assumption of a real minimum-wage [Brecher (1974)] is another popular assumption but would not add any explanatory power to this one-sector economy. Alternatively, an interesting specification that would significantly add to the complexity of the model is one where $\mathrm{w}$ would adjust at a rate proportional to the divergence between its equilibrium value $\overline{\mathrm{w}}$ and its current value $\mathrm{w}$ : $\mathrm{w}=$ $\mu(\overline{\mathrm{w}}-\mathrm{w})$ where the equilibrium nominal wage is the value that would keep aggregate output at its full employment level.

8. If the underlying utility function displays constant relative risk aversion, the solution of the lifetime consumption problem implies that, under some further assumptions, the portfolio allocation decision is separable from the saving decision and that the consumption and the optimal portfolio rule are function of wealth [Tobin (1965), Merton (1969)]. This specification of the consumption expenditure would defy, however, the global uniqueness of the solution in the neighbourhood of the steady state when running numerical solutions.

9. The model presented here is one of the non-monetary economy. This seems a rather good approximation of reality because, in Europe, the banking sector alone employs between 2.5 and $3 \%$ of the labor force $(7 \%$ in Luxemburg). The following production function for the financial 
intermediairies could, however, be introduced: $q=(L / \beta)$ where $q$, the amount of financial services produced, is a proportion $1 / \beta$ of $\mathrm{L}$, the amount of labor. Since $\mathrm{q}=2 \varepsilon \mathrm{p}_{\mathrm{k}} \mathrm{K}$ in the model, the amount of input $\mathrm{L}$ is determined. Increased efficiency through deregulation then leads to a reduction in $\mathrm{L}$. This result would, however, square with the US experience [Ott (1987)] and would not take into consideration the displacement of the geographic location of the financial centers in Europe [Grilli (1989)].

10. A non-negative gain for savers is instrumental in obtaining clear cut results for the short-run equilibrium. A net loss is readily analyzed but is graphically more involving.

11. The presence of capital gains on the existing stock of capital in this quadrant would only reinforce this conclusion.

12. Since the QUEST model provides only one country estimate for $b^{\prime}$, the information is assumed common to all countries.

13. The initial equilibrium is characterized as follows: $\mathrm{F}_{1}=0.1 ; \mathrm{F}_{2}=1$; $\mathrm{i}=0.1 ; \mathrm{i}^{*}=0.09 ; \quad \mathrm{p}=\mathrm{p}_{\mathrm{k}}=1 ; \mathrm{Y}=\mathrm{Y}_{\mathrm{d}}=1 ; \mathrm{L}=0.9 ; \varepsilon=0 ; \mathrm{A}=1.72$; $\mathrm{M}=0.72 ; \mathrm{K}_{\mathrm{d}}=\mathrm{K}=1 ; \theta=1$.

14. The random numbers are generated by the GO5CBF, GO5CCF, GO5DAF and GO5DDF routines of the NAG Fortran Library. Note that in order to arrive at 1000 stable replications, between 0 (NL) to 91.8 (UK) percent of the drawings with unstable properties had to be rejected. Drawings 
with unstable properties are particularly frequent for IT and UK because of low estimates of $\mu^{*}$, the Marshall-Lerner condition being not always met.

15. The probability of a negative value is intended to issue some warning in that, though the range of chosen parameters is reasonable, and lead to e.g. a positive value on average, some particular combination of them might lead to (many) responses with the opposite sign.

16. As $\mathrm{K}$ and $\mathrm{L}$ increase in most countries the incidence on the income distribution is not expected to be strong. The mean change in the share of labor in disposable income, $\mathrm{d}\left(\mathrm{wL} / \mathrm{Y}_{\mathrm{d}}\right) * 100$, is the following: -.33 (BL), -.13 (FR), -.08 (IT), .004 (NL), $\quad-.02$ (UK). The probabilities of $\begin{array}{lllllllllll}\text { a negative response vary as well: } & .73 & \text { (BL), } & .59 & \text { (FR), } & .61 & \text { (IT), } & .31\end{array}$ $(\mathrm{NL}), .33$ (UK). For the $\mathrm{d} \varepsilon$ shock the results do not vary much: magnitudes are of the same order and the signs of changes are similar.

\section{Appendix 1 Glossary of Variable Names}

$$
\begin{aligned}
& \mathrm{A} \quad \text { real value of privately held assets } \\
& \mathrm{B}_{\mathrm{s}}=\text { trade balance } \\
& \mathrm{B}_{\mathrm{t}} \quad=\text { balance of services } \\
& \mathrm{C} \quad=\text { real domestic composite consumption } \\
& \mathrm{F}(.) \quad=\text { production function of the non-monetary sector } \\
& \mathrm{i}, \mathrm{i}^{*} \quad=\text { home, foreign base cost of capital } \\
& \mathrm{I} \quad=\text { import demand for foreign goods }
\end{aligned}
$$




$$
\begin{aligned}
& \mathrm{I}^{*} \quad=\text { foreign import of domestic goods } \\
& \mathrm{K} \quad=\text { domestic stock of capital } \\
& \mathrm{K}_{\mathrm{d}} \quad=\text { home country's ownership of capital } \\
& \text { L = labor employment } \\
& \mathrm{M} \quad=\text { real cash balances } \\
& \mathrm{p}, \mathrm{p}^{*}=\text { domestic, foreign commodity price } \\
& \mathrm{p}_{\mathrm{k}} \quad=\text { relative price of capital } \\
& \mathrm{w} \quad=\text { nominal wage of labor } \\
& \mathrm{Y}=\text { non-monetary output } \\
& \mathrm{Y}_{\mathrm{d}} \quad=\text { disposable income } \\
& \mathrm{b}(.)=\text { desired ratio of real cash balances to the real value of capital } \\
& \mathrm{b}^{\prime} \quad=\text { response of asset preferences to a change in the return on equities } \\
& c_{1}, c_{2}=\text { marg. prop. to spend out of disposable income, of real wealth } \\
& \gamma \quad=\text { term reflecting production technology } \\
& \delta \quad=\text { openness of the economy } \\
& \varepsilon, \varepsilon^{*}=\text { domestic, foreign price of financial services } \\
& \theta \quad=\text { indexation parameter } \\
& \lambda \quad=\text { speed of adjustment of capital stock } \\
& \lambda_{1}, \lambda_{2}=\text { eigen values } \\
& \mu, \mu^{*}=\text { domestic, foreign import price elasticity } \\
& \sigma \quad=\text { substitution elasticity between labor and capital }
\end{aligned}
$$

\section{Appendix 2 Definitions and Abbreviations}

This Appendix contains the algebraic abbreviations used in the text. 
First-order differential equation for $\mathrm{K}$

$$
\begin{aligned}
& \mathrm{a}_{1}=1-\lambda \mathrm{a}_{6} / \gamma \mathrm{d}_{1}>0 \text { under general conditions; } \\
& \mathrm{a}_{2}=-\lambda \mathrm{a}_{6}\left[\mathrm{k}\left(1-\mathrm{c}_{1}+\delta\right)+\mathrm{ic}_{1} / \gamma\right] / \mathrm{d}_{1}<0 ; \\
& \mathrm{a}_{3}=\lambda \mathrm{a}_{6}\left[\mathrm{c}_{1} \mathrm{i} /(1+\mathrm{b}(\mathrm{i}))+\mathrm{c}_{2}\right] / \gamma \mathrm{d}_{1}>0 ; \\
& \mathrm{a}_{4}=-\lambda\left[1+\mathrm{ib}^{\prime} \mathrm{a}_{6} \mathrm{c}_{1} \mathrm{~A} / \gamma(1+\mathrm{b}(\mathrm{i}))^{2}\right]<0 \text { under general conditions; } \\
& \mathrm{a}_{5}=-\lambda\left[1-\mathrm{ib} \mathrm{a}_{6} \mathrm{c}_{1} \mathrm{~A} / \gamma(1+\mathrm{b}(\mathrm{i}))^{2}\right]<0 ; \\
& \left.\mathrm{a}_{6}=\left[-\mathrm{F}_{12} / \mathrm{F}_{22}+\mathrm{i} \delta /(1-\theta)(1-\delta)\right)\right]>0 .
\end{aligned}
$$

First-order differential equation for A

$$
\begin{aligned}
& \mathrm{b}_{1}=1+\mathrm{b}_{6} \pi_{1}>1 ; \\
& \mathrm{b}_{2}=-\left(1-\mathrm{c}_{1}\right)\left[\mathrm{i}\left(1+\gamma \mathrm{kb}_{6}\right)-\left(1+\mathrm{ib}_{6}\right) \pi_{2}\right]<0 \text { for low values of } \\
& \delta ; \\
& \mathrm{b}_{3}=-\left[\mathrm{c}_{2}-\mathrm{i}\left(1-\mathrm{c}_{1}\right) /(1+\mathrm{b}(\mathrm{i}))-\left(1-\mathrm{c}_{1}\right)\left(1+\mathrm{i} \mathrm{b}_{6}\right) \pi_{1}\right]<0 \text { for } \\
& \quad \text { restricted values of } \mathrm{c}_{1} \text { and } \mathrm{c}_{2} ; \\
& \mathrm{b}_{4}=\left(1-\mathrm{c}_{1}\right)\left[\left(1+\mathrm{i} \mathrm{b}_{6}\right) \pi_{3}-\mathrm{i} \mathrm{b}^{\prime} \mathrm{A} /\left(1+\mathrm{b}_{\left.(\mathrm{i}))^{2}\right]>0}{ }^{2}\right]\right. \\
& \mathrm{b}_{5}=-\mathrm{b}_{4}<0 ; \\
& \mathrm{b}_{6}=\delta \mathrm{K}_{\mathrm{d}} / \gamma(1-\theta(1-\delta))>0 ; \\
& \mathrm{h}_{1}=\lambda(1-\delta) \pi_{1} / \gamma(1-\theta(1-\delta))>0 ; \\
& \mathrm{h}_{2}=\left(1-\mathrm{c}_{1}\right)\left(1+\mathrm{i} \delta \mathrm{b}_{6}\right) / \mathrm{d}_{1}+\gamma \mathrm{b}_{6} \mathrm{k}-\mathrm{b}_{6} \pi_{2}>0
\end{aligned}
$$

Aggregate demand

$$
\begin{aligned}
& \pi_{1}=\left[c_{1} \mathrm{i} /(1+\mathrm{b}(\mathrm{i}))+\mathrm{c}_{2}\right] / \mathrm{d}_{1}>0 \\
& \pi_{2}=\left[\gamma \mathrm{k} \mathrm{d}_{2}-\mathrm{c}_{1} \mathrm{i}\right] / \mathrm{d}_{1}>{ }_{<} 0 \\
& \pi_{3}=-\mathrm{ib}^{\prime} \mathrm{c}_{1} \mathrm{~A} /(1+\mathrm{b}(\mathrm{i}))^{2} \mathrm{~d}_{1}>0 \\
& \mathrm{~d}_{1}=\left(1-\mathrm{c}_{1}\right)+\delta+\mathrm{d}_{2}>0 \text { if } \mathrm{d}_{2}>0
\end{aligned}
$$




$$
\begin{aligned}
\mathrm{d}_{2}= & {\left[\delta \mathrm{Y}\left(\mu^{*}+\mu-1\right)-\mathrm{i} \delta \mathrm{c}_{1} \mathrm{~K}_{\mathrm{d}}\right] / \gamma(1-\theta(1-\delta))>_{<} 0 \text { but constrained } } \\
& \text { to be positive. }
\end{aligned}
$$

\section{References}

Bank of England (1989), Quarterly Bulletin, Vol. 29, No. 4.

Brandsma, A., Op de Beek, J., O'Sullivan, L. and Röger, W. (1991), "QUEST: A Macroeconomic Model for the Countries of the European Community as Part of the World Economy", European Economy, March, No. 47.

Brecher, R.A. (1974), "Minimum Wage Rates and the Pure Theory of International Trade", Quarterly Journal of Economics, 88, 98-116.

Bruce, N. and Purvis, D.D. (1985), "The Specification of Goods and Factor Markets in Open Economy Macroeconomic Models", in Jones, R.W. and Kenen, P.B. (eds.), Handbook of International Economics (Amsterdam: North Holland), Vol. II, 807-857.

Capoglu, G. (1990), "The Effect of Financial Liberalization on the Efficiency of the Turkish Financial System: 1980-88", presented during the Lisbon EEA Meeting.

Cho, D.C., Eun, C.S. and Senbet, L.W. (1986), "International Arbitrage Pricing Theory: an Empirical Investigation", Journal of Finance, 46, 2, 313-329.

Dornbusch, R. and Reynoso, A. (1989), "Financial Factors in Economic Development", American Economic Review, 79, No. 2, 204-209.

Eurostat (1990), National Accounts ESA, Aggregates.

Folkerts-Landau, D. and Mathieson, D.J. (1989), "The European Monetary System in the Context of the Integration of European Financial Markets", International Monetary Fund, Occasional Paper No. 66.

Frenkel, J.A. and Rodriguez, C.A. (1975), "Portfolio Equilibrium and the Balance of Payments: A Monetary Approach", American Economic Review, $65,674-688$.

Fry, M. (1988), Money, Interest Rates and Banking in Economic Development, (Baltimore: John Hopkins University Press).

Giovannini, A. and Mayer, C. (1991), European Financial Integration, (Cambridge: The Cambridge University Press). 
Goldstein, M. and Khan, M.S. (1985), "Income and Price Effects in Foreign Trade", in Jones, R.W. and Kenen, P.B. (eds.) Handbook of International Economics, (Amsterdam: North-Holland), Vol. II, 1041-1105.

Grilli, V. (1989), "Europe 1992: Issues and Prospects for the Financial Markets", Economic Policy, 9, 388-421.

Marston, R.C. (1985), "Stabilization Policies in Open Economies", in Jones, R.W. and Kenen, P.B. (eds.), Handbook of International Economics, (Amsterdam: North-Holland), Vol. II, 859-916.

Melitz, J. and Bordes, C. (1991), "The Macroeconomic Implications of Financial Deregulation", European Economic Review, 35, 155-178.

Merton, R.C. (1969), "Lifetime Portfolio Selection under Uncertainty: the Continuous Time Case", Review of Economics and Statistics, 51, 247-257.

Modigliani, F. and Tarantelli, E. (1975), "The Consumption Function in a Developing Economy and the Italian Experience", American Economic Review, 65, 825-842.

Neven, D.J. (1989), "Structural Adjustment in European Retail Banking: Some Views from Industrial Organization", CEPR Discussion Paper No. 311.

OECD (1989), Financial Statistics Part 3, Non-Financial Enterprises Financial Statements.

Ott, M. (1987), "The Growing Share of Services in the US Economy: Degeneration or Evolution?", The Federal Reserve Bank of St. Louis, 69 , No. 6, 5-22.

Price Waterhouse (1988), "The Cost of Non-Europe in Financial Services", in Research of the Cost of Non-Europe, Commission of the European Communities, $\overline{\text { Vol. }} 9$.

Steinherr, A. and Gilibert, P.-L. (1989), "The Impact of Financial Market Integration on the European Banking Industry", CEPS Financial Markets Unit, Research Report No. 1.

Tobin, J. (1965), "The Theory of Portfolio Selection", in Hahn F. and Brechling, F.P.R. (eds.), The Theory of Interest Rates (London: Macmillan), 3-51.

Van Dijk, H.K. and Kloek, T. (1982), "Posterior Moments of the Klein-Goldberger Model" in Goel, P.K. and Zellner, A. (eds.), Bayesian Inference and Decision Techniques with Applications (Amsterdam: North Holland), 95-108. 